\title{
Analisis Kemampuan Literasi Matematis Siswa
}

\author{
Ahmad Muzaki ${ }^{*}$ dan Masjudin² \\ 1*,2Program Studi Pendidikan Matematika, IKIP Mataram \\ Jalan Pemuda No 59A, Dasan Agung Baru, Mataram, NTB, Indonesia \\ 1*ahmadmuzaki@ikipmataram.ac.id
}

Artikel diterima: 13-08-2019, direvisi: 22-09-2019, diterbitkan: 30-09-2019

\begin{abstract}
Abstrak
Tuntutan kemampuan siswa dalam matematika tidak sekedar memiliki kemampuan berhitung saja, akan tetapi mampu menggunakannya dalam pemecahan masalah sehari-hari. Penelitian ini bertujuan untuk menganalisis kemampuan literasi matematis siswa kelas XI SMAN 1 Kediri. Metode penelitian yang digunakan adalah deskriptif kualitatif. Subjek penelitian terdiri dari 6 siswa dari 26 total siswa dalam 1 kelas. Penelitian ini memperhatikan faktor kemampuan awal matematis siswa (KAM). Berdasarkan hasil penelitian, 19\% siswa tergolong kategori KAM tinggi dapat menyelesaikan soal rutin, menginterpretasikan masalah dan menyelesaikannya dengan rumus, melaksanakan prosedur dengan baik, mampu untuk mengatasi situasi yang kompleks serta menggunakan penalarannya dalam menyelesaikan masalah, serta siswa mampu bekerja secara efektif serta menginterpretasikan representasi yang berbeda kemudian menghubungkannya dengan dunia nyata (Level 4).Siswa yang tergolong kategori KAM sedang (66\%)dapat menyelesaikan soal rutin, menginterpretasikan masalah dan menyelesaikannya dengan rumus, serta melaksanakan prosedur dengan baik (Level 3). Siswa dengan kategori KAM rendah (15\%) hanya mampu menyelesaikan soal rutin (level 1).

Kata Kunci: Kemampuan awal matematis, kemampuan literasi matematis, deskriptif kualitatif.
\end{abstract}

\section{Analysis of Mathematical Literacy Ability of Students}

\begin{abstract}
Demands on the ability of students in mathematics cannot just have the ability to count alone, but they can use it in solving everyday problems. This study aims to analyze the mathematical literacy ability of students at grade XI of SMAN 1 Kediri. The research method used was descriptive qualitative. The research subjects consisted of 6 students from 26 total students in 1 class. This study pays attention to the student's initial mathematical ability (IMA) factor. Based on the results of the study, 19\% students who had high IMA could solve routine problems, interpreted problems and solved them with formulas, carried out procedures well, we're able to overcome complex situations and used reasoning in problem-solving, and they were able to work effectively and interpreted representations that were different then connected it to the real world (Level 4). Students who had medium IMA (66\%) were able to solve routine problems, interpreted problems and solved them with formulas, and carried out procedures well (Level 3). While students who had low IMA (15\%) were only able to solve routine problems (level 1).

Keyword: Mathematical initial ability, mathematical literacy ability, qualitative description.
\end{abstract}




\section{Pendahuluan}

Program for International Student Assesment (PISA) merupakan salah satu program yang diinisiasi oleh OECD (Organisation for Economic Cooperation and Development) pada Tahun 1990an yang merupakan salah satu assesmen utama berskala internasional yang menilai kemampuan matematika siswa dan memberikan informasi kepada pemerintah maupun pihak lainnya tentang bagaimana tingkat efektivitas sistem pendidikan khususnya dalam mempersiapkan masa depan siswa (Kaye \& Rose 2015). OECD melalui PISA melakukan penilaian mengenai kemampuan membaca siswa dan literasi matematis siswa secara rutin setiap tiga tahun sejak Tahun 2000. Berdasarkan hasil asesmen PISA 2000, 2003, 2006, 2009 dan 2012, pencapaian kemampuan literasi matematis siswa, belum ada yang mencapai level tertinggi yakni pada level 6. Berdasarkan asessmen PISA 2000, 2003, 2006, 2009 dan 2012, terdapat $76 \%$ anak Indonesia yang tidak mencapai level 2 (minimal keluar dari kategori low achievers), sedangkan jumlah siswa yang mencapai level tertinggi 5 hanya 0,3\% (Baswedan, 2014). Hasil PISA 2000, 2003, 2006, 2009 dan 2012ini mengindikasikan siswa di Indonesia masih berada pada level 1.

Di lain pihak, penelitian yang dilakukan oleh Asmara \& Rochmad (2017), diperoleh siswa yang berkemampuan sedang dan tinggi hanya bisa menyelesaikan soal pada level 3 sedangkan siswa yang berkemampuan rendah hanya bisa menyelesaikan soal pada level 1. Hal senada juga diperoleh pada penelitian yang dilakukan oleh Fiad, Suharto dan Kurniati (2017) kemampuan literasi matematis siswa maksimal diperoleh pada level 3. Hal ini menunjukkan bahwa kemampuan literasi matematis siswa masih rendah. Padahal kemampuan literasi matematis ini sangat penting.

Selain itu, beberapa penelitian sebelumnya telah menggunakan soal-soal PISA dalam penelitiannya dengan dikaitkan pada variable lain, yaitu: analisis kemampuan pemecahan masalah matematis siswa melalui soal PISA (Nadhifah \& Afriansyah, 2016); pengembangan soal matematika realistic berdasarkan soal PISA (Mangelep \& Kaunang, 2018); analisis pemahaman konsep pada soal PISA (Puspitasari \& Ratu, 2019; Winarsih \& Mampouw, 2019)

Kemampuan literasi matematis sangat penting karena matematika sangat erat kaitannya dengan kehidupan sehari-hari (Sari, 2015). Kemampuan literasi matematis dapat meningkatkan sumber daya manusia (Masjaya \& Wardono, 2018). Literasi matematis dapat membantu seseorang untuk memahami peran atau kegunaan matematika dalam kehidupan sehari-hari. Di samping itu juga literasi matematis menekankan pada kemamapuan siswa untuk menganalisis, memberi alasan dan mengkomunikasikan ide secara efektif pada pemecahan 
masalah matematis yang mereka temui (OECD, 2009).

Hal inilah yang menghubungkan matematika yang dipelajari di ruang kelas dengan berbagai macam situasi dunia nyata. Menurut Abdussakir (2018) menyatakan literasi matematis tidak hanya melibatkan penggunaan prosedurprosedur, tetapi menuntut dasar pengetahuan dan kompetensi serta rasa percaya diri untuk mengaplikasikan pengetahuannya dalam kehidupan seharihari. Hal ini berarti, seseorang yang memiliki kemampuan literasi matematis dapat mengestimasi, menginterpretasi data serta dapat menyelesaikan masalah dalam kehidupan sehari-hari. Karena kita ketahui bersama bahwa masalah merupakan hal yang sangat penting di dalam matematika. Masalah pada matematika membuat siswa menjadi lebih banyak pengetahuan, lebih berpengalaman dan dapat menjadikan siswa menjadi lebih dewasa. Selain itu, pemahaman tentang matematika sangat penting bagi kesiapan siswa untuk hidup dalam masyarakat modern karena matematika merupakan alat penting bagi siswa ketika mereka menghadapi masalah dalam kehidupan sehari-hari (Muzaki, 2017).

Literasi matematis juga sejalan dengan tujuan pembelajaran matematika di Indonesia (Wardhani \& Rumiati, 2011). Kartadinata (2011) menyatakan bahwa tujuan utuh pendidikan adalah tujuan individual, tujuan kolektif, dan tujuan eksistensial. Tujuan individual yaitu tujuan yang harus dicapai oleh setiap siswa dalam mengembangkan potensi dirinya. Tujuan kolektif adalah tujuan yang harus dicapai dalam wujud kecerdasan kehidupan bangsa. Sedangkan tujuan eksistensial adalah tujuan yang harus terwujud dalam karakter bangsa yang bermartabat yang memiliki daya saing dan ketahanan hidup yang kokoh.

Tuntutan kemampuan siswa dalam matematika tidak sekedar memiliki kemampuan berhitung saja, akan tetapi kemampuan berpikir yang logis, kritis dan sistematis dalam pemecahan masalah. Pemecahan masalah ini bukan hanya berupa soal rutin akan tetapi lebih kepada permasalahan yang dihadapi sehari-hari. Kemampuan matematis demikian ini yang disebut sebagai kemampuan literasi matematis. Seseorang yang memiliki kemampuan literasi (melek) matematis tidak sekedar paham tentang matematika namun mampu menggunakannya dalam pemecahan masalah sehari-hari.

Selain itu, hasil kajian beberapa penelitian sebelumnya mengkaji pentingnya kemampuan literasi matematis siswa untuk dikaji, yaitu: 1) Analisis mahasiswa calon guru (Prabawati, 2018); 2) Pengembangan soal matematika realistic (Mangelep \& Kaunang, 2018); 3) Konsep operasi bilangan pecahan (Suwarto, 2018); dan 4) Pengembangan LKS berbasis masalah (Prabawati, Herman, \& Turmudi, 2019).

Berdasarkan uraian di atas, maka peneliti akan melakukan penelitian tentang analisis kemampuan literasi 
matematis siswa kelas XI SMA Negeri 1 Kediri untuk melihat perkembangan serta capaian kemampuan literasi matematis siswa ditinjau dari kemampuan awal matematis siswa (KAM) mengingat pentingnya kompetensi-kompetensi matematis yang harus dimiliki oleh siswa.

\section{Metode}

Jenis penelitian yang digunakan adalah penelitian deskriptif kualitatif yang bertujuan mendeskripsikan kemampuan literasi matematis siswa ketika menyelesaikan soal matematika. Pendekripsian ini ditelusuri melalui pengamatan langsung dalam proses menyelesaikan soal yaitu menganalisis pekerjaan siswa dalam merumukan soal, menyelesaikan soal tersebut dan melihat indikator ketercapaian berdasarkan indikator kemampuan literasi matematis siswa.

Penelitian ini akan dilaksanakan pada bulan Mei Tahun Pelajaran 2018/2019 di SMA Negeri 1 Kediri yang berlokasi di Kecamatan Kediri, Kabupaten Lombok Barat.

Subjek penelitian yaitu kelas XI SMA Negeri 1 Kediri yang terdiri dari 26 siswa. Dari 26 siswa dipilih 6 siswa yang terdiri dari 2 KAM tinggi, 2 KAM sedang dan 2 KAM rendah untuk diberikan treatment lebih lanjut guna mendapatkan informasi lebih dalam pada penelitian ini.

Berikut daftar siswa yang mendapatkan treatment lebih lanjut disajikan pada tabel 1.

\section{Hasil dan Pembahasan}

Hasil yang diperoleh pada penelitian ini adalah pencapaian kemampuan literasi matematis siswa. Berikut hasil pekerjaan siswa untuk setiap leveldisajikan pada table 2 .

Level 1. Siswa dapat menggunakan pengetahuannya untuk menyelesaikan soal rutin, dan dapat menyelesaikan masalah yang konteksnya umum.

Berdasarkan penyelesaian subjek $\mathrm{S}_{1}$ mengenali ide dominan dalam menyelesaikan masalah yang sedang dihadapi dengan cara menuliskan apa yang

Tabel 1.

Kriteria Pengelompokan Kemampuan Awal

\begin{tabular}{cc}
\multicolumn{2}{c}{ Matematis (KAM) } \\
\hline Nilai KAM & $\begin{array}{c}\text { Kategori } \\
\text { Kemampuan Awal } \\
\text { Matematika } \\
\text { (KAM) }\end{array}$ \\
\hline$K A M \geq \bar{x}+S B$ & Tinggi \\
\hline $\bar{x}-S B \leq K A M<\bar{x}+S B$ & Sedang \\
\hline$K A M<\bar{x}-S B$ & Rendah \\
(Sumber $:$ Indrawati Muzaki, Febrilia, 2019: 71)
\end{tabular}

Tabel 2.

Daftar Subjek Penelitian Wawancara

\begin{tabular}{|ccc|}
\hline Kategori & Nama & Kode \\
\hline \multirow{2}{*}{ KAM Tinggi } & EN & S1 \\
\cline { 2 - 3 } & MAT & S2 \\
\hline \multirow{2}{*}{ KAM Sedang } & ARB & S3 \\
\cline { 2 - 3 } & BLL & S4 \\
\hline KAM Rendah & EB & S5 \\
\cline { 2 - 3 } & LMP & S6 \\
\hline
\end{tabular}

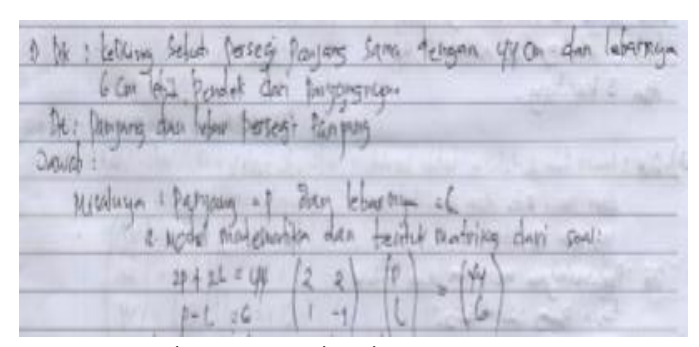

Gambar 1. Hasil Pekerjaan S1 no. 1. 
diketahui dan ditanyakan dari permasalahan itu (lihat gambar 1). Subjek $\mathrm{S}_{1}$ memisalkan dan merancang model matematika dari soal tersebut kemudian menyusun dalam bentuk matriks.

Jawaban $S_{2}$ untuk soal nomor 1 , menunjukkan bahwa $S_{2}$ mampu mengenali ide dominan dari masalah dengan baik yaitu dengan mampu menyebutkan inti permasalahan (lihat gambar 2). $\mathrm{S}_{2}$ menyebutkan apa yang diketahui dan apa yang ditanyakan dengan benar, lengkap dan secara sederhana. Subjek $S_{2}$ juga mampu memilih dan mencari cara penyelesaian masalah. Subjek tersebut mampu menyelesaikan soal sesuai strategi yang dibangun, sebelum melakukan perhitungan subjek $S_{2}$ menuliskan terlebih dahulu keterangan pada cara penyelesaian dengan menggunakan pemisalan dan mampu menuliskan penyelesaian yang sesuai dengan permasalahan. Berdasarkan jawaban yang ditulis subjek $S_{2}$ alternatif jawabannya tidak menuliskan langkahlangkah penyelesaian dengan runtut. Pada alternative jawaban solusi diperoleh benar serta subjek $\mathrm{S}_{2}$ mampu memberi kesimpulan secara sederhana.

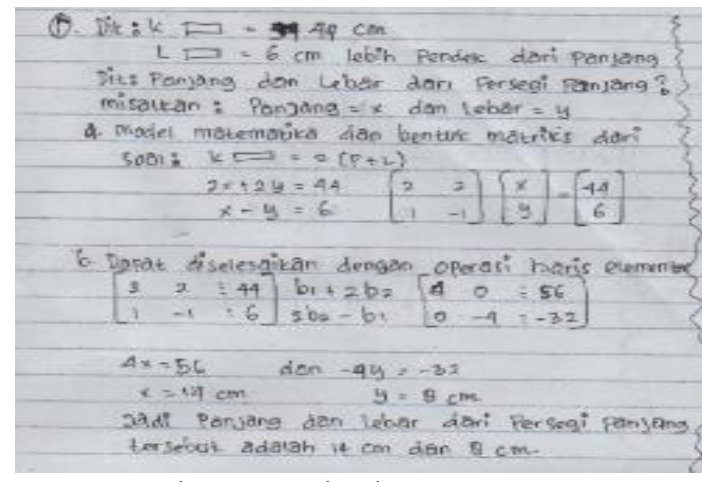

Gambar 2. Hasil Pekerjaan S2 no. 1.
Untuk soal nomor 1 subjek $\mathrm{S}_{3}$ membaca soal dan memahami setiap informasi yang ada pada soal tersebut. Subjek $\mathrm{S}_{3}$ dapat menemukan inti permasalahan yang diketahui dan ditanyakan dalam soal (lihat gambar 3). Subjek $\mathrm{S}_{3}$ dapat menemukan cara yang berbeda tanpa berpatokan pada contoh yang diberikan oleh guru di kelas. Subjek $\mathrm{S}_{3}$ hanya menggunakan satu cara dalam menyelesaikan soal tersebut. Subjek $S_{3}$ dapat menyelesaikan persoalan tersebut dengan melaksanakan langkah sesuai dengan strategi yang dibangun.

Jawaban $\mathrm{S}_{4}$ untuk soal nomor 1 ,

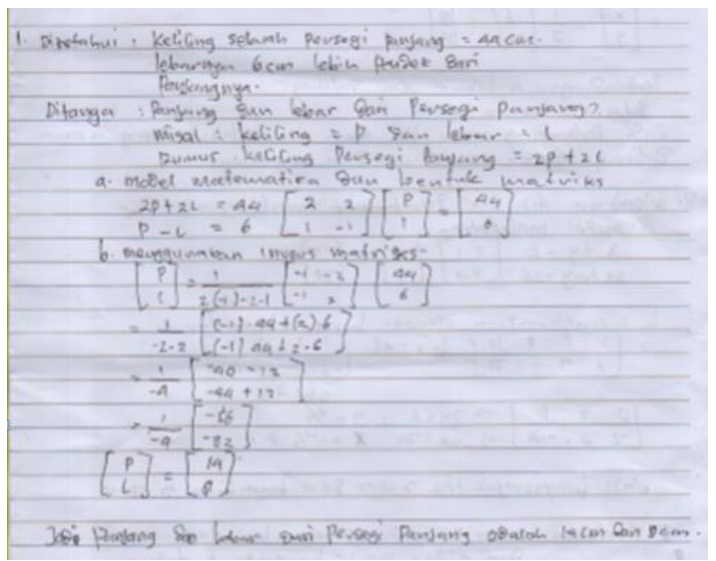

Gambar 3. Hasil Pekerjaan S3 no. 1.

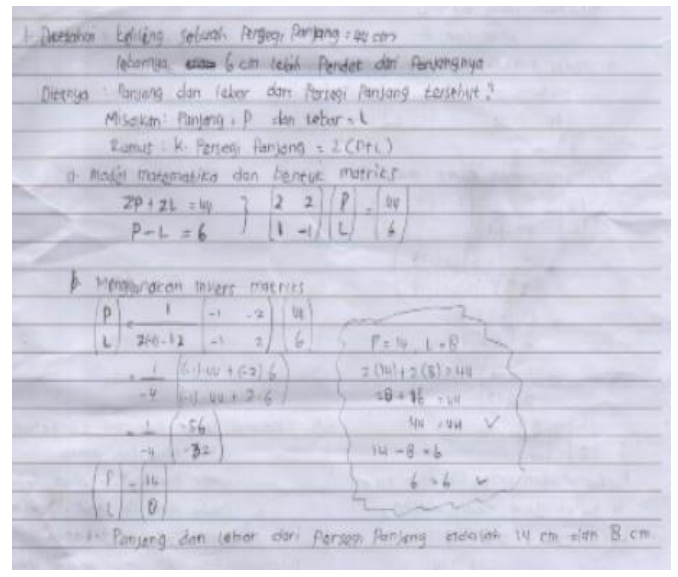

Gambar 4. Hasil Pekerjaan S4 no. 1. 
menunjukkan bahwa $\mathrm{S}_{4}$ mampu memahami soal dengan menyebutkan dan menuliskan kembali yang diketahui dan yang ditanyakan (lihat gambar 4). Menggunakan pemisalan, merancang model matematika dan membuat dalam bentuk matriks. Saat akan mulai menyelesaikan soal subjek menjelaskan cara apa yang akan digunakan dalam menyelesaikan soal. Langkah-langkah penyelesaian $S_{3}$ pada jawabannya tidak runtut, artinya subjek tersebut mampu berpikir untuk menyelesaikannya.

Untuk soal nomor 1 subjek $S_{5}$ tidak menuliskan kembali yang diketahui dan yang ditanyakan, namun subjek langsung menuliskan model matematika dan membuatnya dalam bentuk matriks (lihat gambar 5). Subjek $S_{5}$ menyelesaikan soal tersebut menggunakan operasi baris elementer dengan langkah penyelesaian yang tidak runtut dan subjek $S_{5}$ juga dapat menarik kesimpulan secara sederhana. Hal tersebut ditunjukkan bahwa subjek $\mathrm{S}_{5}$ kurang lengkap dalam memaparkan informasi sesuai dengan masalah pada soal, sehingga dapat dikatakan $S_{5}$ tidak

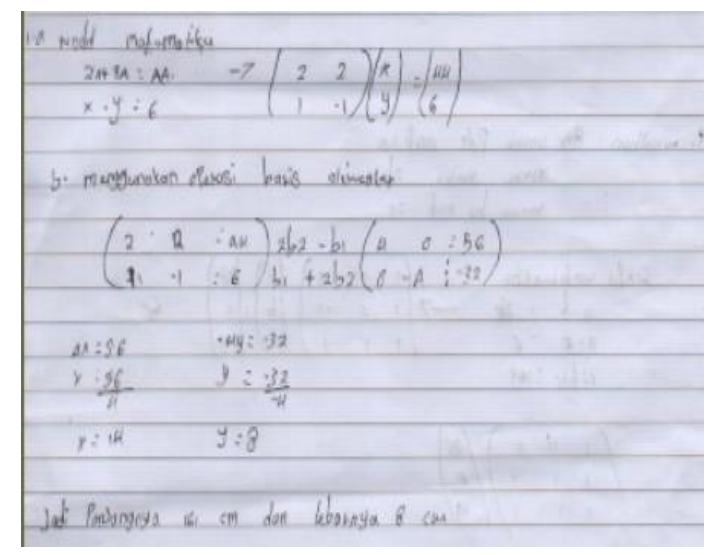

Gambar 5. Hasil Pekerjaan S5 no. 1. mampu mengenali ide dominan, tidak mampu memeriksa kembali jawaban.

Jawaban subjek $S_{6}$ pada soal nomor 1 menunjukkan bahwa subjek tidak dapat menuliskan kembali apa yang diketahui dan yang ditanyakan namun subjek langsung hanya menuliskan model matematika dan menyusunnya dalam bentuk matriks (lihat gambar 6 ). Subjek $\mathrm{S}_{6}$ juga menggunakan rencana penyelesaian operasi baris elementer. Pada langkah penyelesaiannya subjek S6melakukan kesalahan yakni tidak teliti dalam menghitung sehingga hasil akhir yang diperoleh salah. Hal ini berakibat kesimpulannya menjadi salah.

Berdasarkan uraian di atas, siswa kategori KAM tinggi dapat menyelesaikan soal rutin, menginterpretasikan masalah dan menyelesaikannya dengan rumus, melaksanakan prosedur dengan baik, mampu mengatasi situasi yang kompleks dan menggunakan penalarannya dalam menyelesaikan masalah, serta siswa mampu bekerja secara efektif, menginterpretasikan representasi yang berbeda kemudian menghubungkannya

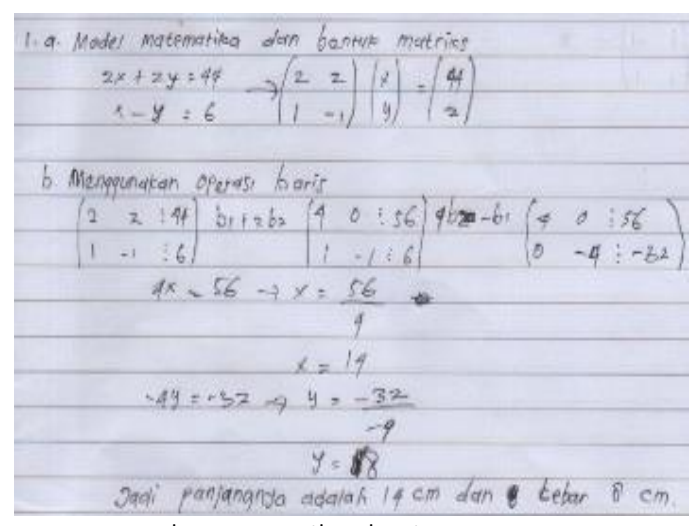

Gambar 6. Hasil Pekerjaan S6 no. 1. 
dengan dunia nyata (Level 4). Siswa kategori KAM sedang dapat menyelesaikan soal rutin, menginterpretasikan masalah dan menyelesaikannya dengan rumus, serta melaksanakan prosedur dengan baik (Level 3). Siswa kategori KAM rendah hanya mampu menyelesaikan soal rutin (level 1).

Untuk siswa yang tergolong kategori KAM tinggi, Pada aspek mengenali masalah yang sedang dihadapi, kedua subjek mampu menyebutkan yang diketahui dan yang ditanyakan pada soal dengan jelas, tepat dan teliti. Kedua subjek pada kategori ini mampu membuat keterangan, merancang model matematika dan menyusunnya dalam bentuk matriks. Hal ini sesuai dengan pendapat De Bono (Kusmarini \& Yusita, 2014) yang menyatakan bahwa mereka yang tidak prosedural lebih mahir dalam memperoleh suatu bentuk yang jelas dari situasi yang sedang dihadapi hanya dengan satu kalimat saja.

Siswa yang tergolong KAM sedang pada aspek mengenali masalah yang sedang dihadapi, kedua subjek mampu menyebutkan yang diketahui dan yang ditanyakan pada soal dengan jelas, tepat dan teliti. Kedua subjek pada kategori ini mampu membuat keterangan, merancang model matematika dan menyusunnya dalam bentuk matriks.

Siswa kategori KAM rendah pada aspek mengenali ide dominan dari masalah yang sedang dihadapi, kedua subjek masih bingung dalam memehami soal, tidak mampu mengenali ide dominan dari soal secara baik. Subjek sering kali tidak lengkap menuliskan dan menjelaskan inti permasalahan dari soal yang dikerjakan. Hal ini sesuai dengan pendapat Kusmarini \& Yusita (2014) yang menyatakan bahwa gagasan dominan tidak terletak dalam situasi itu sendiri, melainkan tereletak dalam pengamatan seseorang.

\section{Penutup}

Berdasarkan pembahasan yang dilakukan di atas, maka dapat disimpulkan secara umum siswa baik tergolong kategori KAM tinggi, sedang dan rendah memiliki kemampuan literasi rendah. Hal ini terlihat pada kemampuan siswa dalam menyelesaikan soal yang masih terbiasa dengan jawaban prosedural dan sifatnya konkret. Siswa juga masih belum terbiasa dengan soal-soal yang membutuhkan pemikiran logis, kritis dan solusi yang aplikatif. Sekitar 78\% siswa dapat menyelesaikan soal rutin, $58 \%$ siswa dapat menginterpretasikan masalah dan menyelesaikannya dengan rumus, 65\% siswa dapat melaksanakan prosedur dengan baik, 19\% siswa mampu untuk mengatasi situasi yang kompleks serta menggunakan penalarannya dalam menyelesaikan masalah, serta 54\% siswa mampu bekerja secara efektif serta menginterpretasikan representasi yang berbeda kemudian menghubungkannya dengan dunia nyata. Berdasarkan hasil penelitian, 19\% siswa kategori KAM tinggi dapat menyelesaikan soal rutin, 


\begin{abstract}
menginterpretasikan masalah dan menyelesaikannya dengan rumus, melaksanakan prosedur dengan baik, mampu untuk mengatasi situasi yang kompleks serta menggunakan penalarannya dalam menyelesaikan masalah, serta siswa mampu bekerja secara efektif serta menginterpretasikan representasi yang berbeda kemudian menghubungkannya dengan dunia nyata. $66 \%$ siswa kategori KAM sedang dapat menyelesaikan soal rutin, menginterpretasikan masalah dan menyelesaikannya dengan rumus, serta melaksanakan prosedur dengan baik. 15\% siswa kategori KAM rendah hanya mampu menyelesaikan soal rutin.
\end{abstract}

Merujuk pada pembahasan dalam penelitian ini, maka peneliti menyarankan untuk peneliti selanjutnya agar melakukan penelitian sejenis maupun yang lebih mendalam mengingat pentingnya kemampuan literasi matematis siswa. Variasi soal juga sebaiknya lebih variatif untuk menjaring data yang lebih efektif.

\section{UCAPAN TERIMA KASIH}

Penulis menyampaikan terimakasih kepada semua pihak yang telah memberikan dukungan, baik moril maupun materil sehingga artikel ini dapat terselesaikan.

\section{Daftar Pustaka}

Abdussakir. (2018). Makalah disampaikan

\begin{tabular}{lrr} 
dalam Seminar & $\begin{array}{r}\text { Pendidikan } \\
\text { Matematika }\end{array}$ \\
$\begin{array}{l}\text { Pendidikan } \\
\text { Karakter }\end{array}$ & (Akhlaqul \\
\hline
\end{tabular}

Karimah) dan Kesadaran Literasi Matematika Siswa Melalui Pembelajaran Matematika" oleh Prodi Pendidikan Matematika STKIP PGRI Sumenep, 3 Maret 2018.

Asmara \& Rochmad. (2017). Analisis Kemampuan Literasi Matematika Siswa Kelas $X$ Berdasarkan Kemampuan Matematik. Scholaria, 7(2). 135- 142.

Baswedan, A. (2014). Gawat Darurat Pendidikan di Indonesia. Jakarta: Kementerian Pendidikan dan Kebudayaan Republik Indonesia.

Fiad, Suharto, \& Kurniati, D. (2017). Identifikasi Kemampuan Literasi Matematika Siswa SMP Negeri 12 Jember dalam Menyelesaikan Soal PISA Konten Space and Shape. Kadikma, 8(1). 72-78.

Indrawati, Muzaki, \& Febrilia. (2019). Profil Berpikir Siswa dalam Menyelesaikan Soal Sistem Persamaan Linear. Jurnal Didaktik Matematika, 6(1). 68-83.

Kartadinata, S. (2011). Bimbingan dan Konseling Sebagai Upaya Pedagogis. Bandung: UPI Press.

Kaye, S., \& Rose, T. (2015). Assessing mathematical literacy. New York: Springer International Publishing.

Kusumarini, Y. (2004). Berpikir Lateral Dalam Perspektif Pembelajaran Desain. Dimensi Interior, 2(1). 80 - 96. Mangelep, N. O., \& Kaunang, D. F. (2018). Pengembangan Soal Matematika Realistik Berdasarkan Kerangka Teori Program for International Students Assessment. Mosharafa: Jurnal Mosharafa: Jumal Pendidikan Matematika Volume 8, Nomor 3, September 2019 Copyright $\odot 2019$ Mosharafa: Jurnal Pendidikan Matematika 
Pendidikan Matematika, 7(3), 455466.

DOI: https://doi.org/10.31980/mosharafa.v $7 i 3.157$

Masjaya \& Wardono. 2018. Pentingnya Kemampuan Literasi Matematika untuk Menumbuhkan Kemampuan Koneksi Matematika dalam Meningkatkan SDM. Prisma, 1(1). 568574.

Muzaki, A., Yaya S. K., \& Jozua S. (2017). Learning with Abductive-Pictorial Strategy for Improving Mathematical Proofing Ability of Prosfective Mathematics Teacher. IJSASCS. Vol. 7. 2017.

Nadhifah, G., \& Afriansyah, E. A. (2016). Peningkatan Kemampuan Pemecahan Masalah Matematis Siswa dengan Menerapkan Model Pembelajaran Problem Based Learning dan Inquiry. Mosharafa: Jurnal Pendidikan Matematika, 5(1). 33-44.

OECD. (2009). Learning Mathematics for Life: A Perspective from PISA. Paris: OECD Publishing.

Prabawati, M. N. (2018). Analisis Kemampuan Literasi Matematik Mahasiswa Calon Guru Matematika. Mosharafa: Jurnal Pendidikan Matematika, 7(1), 113-120. DOI: https://doi.org/10.31980/mosharafa.v 7i1.347

Prabawati, M. N., Herman, T., \& Turmudi, T. (2019). Pengembangan Lembar Kerja Siswa Berbasis Masalah dengan Strategi Heuristic untuk Meningkatkan Kemampuan Literasi Matematis.
Mosharafa: Jurnal Pendidikan Matematika, 8(1), 37-48. DOI: https://doi.org/10.31980/mosharafa.v $8 \mathrm{i} 1.383$

Puspitasari, P., \& Ratu, N. (2019). Deskripsi Pemahaman Konsep Siswa dalam Menyelesaikan Soal PISA pada Konten Space and Shape. Mosharafa: Jurnal Pendidikan Matematika, 8(1), 155166.

DOI: https://doi.org/10.31980/moshar afa.v8i1.431

Sari, R. H. N. (2015). Literasi Matematis: Apa, Mengapa dan Bagaimana? Disajikan dalam Seminar Nasional Matematika dan Pendidikan Matematika UNY.

Suwarto, S. (2018). Konsep Operasi Bilangan Pecahan melalui Garis Bilangan. Mosharafa: Jurnal Pendidikan Matematika, 7(3), 327336.

DOI: https://doi.org/10.31980/mosharafa.v $7 i 3.73$

Wardhani, S., \& Rumiati. (2011). Instrumen Penilaian Hasil Belajar Matematika SMP: Belajar dari PISA dan TIMSS. Yogyakarta: KemenDikNas dan PPPPTK.

Winarsih, M., \& Mampouw, H. L. (2019). Profil Pemahaman Himpunan oleh Siswa Berdasarkan Perbedaan Kemampuan Matematika Ditinjau dari Teori APOS. Mosharafa: Jurnal Pendidikan Matematika, 8(2), 249260.

DOI: https://doi.org/10.31980/moshar afa.v8i2.506 


\section{Riwayat Hidup PenUlis}

\section{Dr. Ahmad Muzaki, M.Pd.}

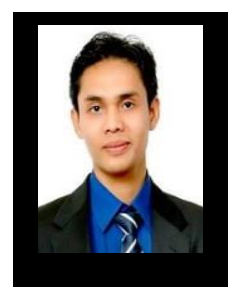

Lahir di Barejulat, 29 Oktober 1986. Staf pengajar di IKIP Mataram. Studi S1 Pendidikan Matematika IKIP Mataram, lulus tahun 2009; S2 Pendidikan Matematika Universitas Negeri Malang, lulus tahun 2012; dan S3 Pendidikan Matematika Universitas Pendidikan Indonesia, Bandung, lulus tahun 2017.

\section{Masjudin, M.Pd.}

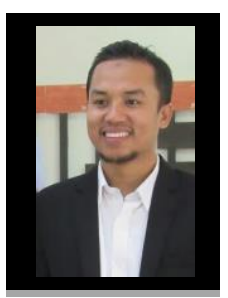

Lahir di Kertasari, 7 Juli 1986. Staf pengajar di IKIP Mataram. Studi S1 Pendidikan Matematika IKIP Mataram, lulus tahun 2009; S2 Pendidikan Matematika Universitas Negeri Malang, lulus tahun 2012. 